\title{
Effect of Welding Parameters on Axial Shortening in Continuous Friction Welded Inconel 718 Superalloy and AISI 316L Stainless Steel
}

\author{
Ömer Karabey ${ }^{1 *}$, Ahmet Akkuş² \\ 1* Sivas Cumhuriyet University, Faculty of Engineering, Departmant of Mechanical Engineering, Sivas, Turkey, (ORCID: 0000-0002-5726-9284), \\ omerkarabey@cumhuriyet.edu.tr \\ 2 Sivas Cumhuriyet University, Faculty of Engineering, Departmant of Mechanical Engineering, Sivas, Turkey, (ORCID: 0000-0002-6881-9333), \\ aakkus@cumhuriyet.edu.tr
}

(2nd International Conference on Applied Engineering and Natural Sciences ICAENS 2022, March 10-13, 2022)

(DOI: 10.31590/ejosat.1081747)

ATIF/REFERENCE: Karabey, Ö. \& Akkuş, A. (2022). Effect of Welding Parameters on Axial Shortening in Continuous Friction Welded Inconel 718 Superalloy and AISI 316L Stainless Steel. European Journal of Science and Technology, (34), 311-316.

\begin{abstract}
In this study, nickel-based Inconel 718 superalloy and iron-based AISI 316L stainless steel were joined by friction welding using 27 different welding parameters. It is aimed to contribute to the literature on determining the initial length of the welded samples for similar applications to be made later by determining the axial shortening of the welded samples. Welding samples which have $12 \mathrm{~mm}$ diameter and $70 \mathrm{~mm}$ length were prepared for Inconel 718 and AISI 316L. In the friction welding machine, AISI 316L stainless steel is attached to the rotating chuck and Inconel 718 superalloy is attached to the linear moving chuck. For continuous friction welding parameters, 3 different rotational speeds (1800-1600-1400 rpm), 3 different friction times for each rotational speed (16-12-6 s) and 3 different friction pressures (60- 40-20 MPa), forge pressure (120-80-40 MPa) and forge time (32-24-12 s) were determined. The axial shortenings of the samples which welded with these parameters were measured with the digital caliper. As a result, the maximum axial shortening was measured as $8.57 \mathrm{~mm}$ in the S1 sample, and the minimum shortening was measured as $1.39 \mathrm{~mm}$ in the S18 sample. When the welded samples are examined in macro terms, it has been seen that the HAZ is narrower on the Inconel 718 side. When the welding specimens were examined, cracks were observed on the flash on the Inconel 718 side. It was observed that axial shortening increased as friction and forge pressure increased at $1800 \mathrm{rpm}$ and $1600 \mathrm{rpm}$. In all samples, the increase in friction and forge time increased axial shortening in length.
\end{abstract}

Keywords: Friction Welding, Inconel 718, AISI 316L, Superalloy, Stainless Steel, Dissimilar metal welds.

\section{Sürtünme Kaynağıyla Birleştirilen Inconel 718 Süperalaşımı ve 316L Paslanmaz Çeliğinde Kaynak Parametrelerinin Eksenel Kısalmaya Etkisi}

$\ddot{\mathbf{O z}}$

Bu çalışmada nikel esaslı Inconel 718 süper alaşımı ve demir esaslı AISI 316L paslanmaz çeliği 27 farklı kaynak parametresi kullanılarak sürekli sürtünme kaynağı ile birleştirilmiştir. Kaynaklanan numunelerin boyca kısalmaları belirlenerek sonrasında yapılacak benzer uygulamalar için kaynak numunelerinin ilk boyunun belirlenmesi konusunda literatüre katkı sunulması amaçlanmaktadır. Inconel 718 ve AISI 316L için $12 \mathrm{~mm}$ çapında ve $70 \mathrm{~mm}$ boyunda kaynak numuneleri hazırlanmıştır. Sürtünme kaynak makinasında döner aynaya AISI 316L paslanmaz çeliği, doğrusal hareketli aynaya ise Inconel 718 süper alaşımı bağlanmıştır.

* Corresponding Author: omerkarabey@,cumhuriyet.edu.tr 
Sürekli sürtünme kaynağı ana etmen olarak 3 farklı devir (1800-1600-1400 dev/dk), her bir devir için 3 farklı sürtünme süresi (16-12$6 \mathrm{~s})$ ve bu sürtünme sürelerinin alt indisi olarak 3 farklı sürtünme basınc1 (60-40-20 MPa), yığma basınc1 (120-80-40 MPa) ve yı̆̆ma süresi (32-24-12 s) seçilmiştir. Bu parametrelerle birleştirilen numunelerde dijital kumpas ile numunelerdeki boyca kısalmalar ölçülmüştür. Sonuç olarak maksimum boyca kısalma S1 numunesinde 8,57 mm, minimum boyca k1salma ise S18 numunesinde 1,39 mm olarak ölçülmüştür. Kaynaklı numuneler makro olarak incelendiğinde ITAB bölgesinin Inconel 718 tarafinda daha dar olduğu görülmüştür. Kaynak çapakları incelendiğinde Inconel 718 tarafinda çapaklarda çatlamalar görülmüştür. $1800 \mathrm{rpm}$ ve $1600 \mathrm{rpm}$ de vir sayısında sürtünme ve yığma basıncı arttıkça boyca kısalmanın arttığı gözlemlenmiştir. Tüm numunelerde sürtünme ve yığma süresinin artışı boyca kısalmayı artırmıştır.

Anahtar Kelimeler: Sürtünme Kaynağı, Inconel 718, AISI 316L, Süperalaşım, Paslanmaz Çelik, Farklı Malzemelerin Kaynağı.

\section{Introduction}

Metals and alloys of these metals, which are difficult to join with fusion welding methods, can be easily joined together by friction welding method. Friction welding is a solid state process used to join two materials with the same or different chemical properties, without any filler material, under a certain force with frictional heat. It is examined under two main headings as friction welding and friction stir welding. Friction welding is generally used to join rod-shaped parts, while friction stir welding is used to join sheet materials. In friction welding, a quality joint can be achieved by configuring the parameters of rotational speed (rpm), friction pressure $(\mathrm{MPa})$, forge pressure $(\mathrm{MPa})$, friction time $(\mathrm{s})$ and forge time (s). At the same time, it is seen that the HAZ (Heat Affected Zone) is quite narrow in friction welding compared to other welding methods. Thus, the part where the metallurgical structure of the welding zone changes remains in a very small region [1-5].

Lalam S.V. et al. welded the nickel-based Inconel 718 superalloy and the EN24 steel alloy by friction welding. They welded the materials with a single parameter, $28 \mathrm{kN}$ friction pressure, $41.73 \mathrm{kN}$ forge pressure, $1422 \mathrm{rpm}$ rotational speed and $5 \mathrm{~mm}$ on burn-off length. The welded parts were subjected to two different heat treatments after welding. The first heat treatment was carried out according to the quenching and tempering data of the EN24 steel alloy. The heat treatment cycle was completed by heating at $850{ }^{\circ} \mathrm{C}$ for 30 minutes, quenching in oil at $220^{\circ} \mathrm{C}$ for 3 hours and then cooling in air. The second heat treatment cycle was performed according to the duplex aging data of Inconel 718. The heat treatment cycle was completed by heating at $1065^{\circ} \mathrm{C}$ for 1 hour, after cooling in air for 10 hours at $760^{\circ} \mathrm{C}$, after cooling in the furnace at $650{ }^{\circ} \mathrm{C}$ for 20 hours and then left to air cool. The microstructure, tensile and yield strength and charpy impact strength were compared in the welds made with these parameters. As a result, friction welding of two dissimilar metals were observed good toughness and low strength compared to base metals. After the first heat treatment, the toughness decreased but the strength increased, after the second heat treatment, a marginal increase in strength and a significant decrease in toughness were observed [6].

Li W-Y. et al. welded 45 (1045) steel with linear friction welding at different friction times (0.5-1-1.5-2-3-4 s). Axial shortenings and flash shapes were compared after welding. As a result, it is stated that a solid weld will be formed in 3 seconds of friction time and the axial shortening increases exponentially with increasing friction time. They have seen that the flash structure in the friction direction is in the form of a wave strip, the flash in the vertical direction is in the form of a curved swirl and the vertical flash is shorter [7].
Rehman A. U. et al. welded Inconel 718 and Inconel 600 nickel-based superalloys by rotary friction welding. They welded with $60 \mathrm{MPa}$ friction pressure, $3 \mathrm{~s}$ friction time, $1500 \mathrm{rpm}$ rotational speed, $80 \mathrm{MPa}$ upset pressure and $6 \mathrm{~s}$ upset time parameters. The tensile strength and microstructure characteristics of welded parts at room temperature were investigated. As a result, they stated that ruptures and unwanted phases did not occur in the welds. Higher hardness and some grain coarsening was observed at the weld interface. Due to grain coarsening, the rupture was occurred in the HAZ [8].

Gobu N. and Mahadevan K. welded nickel-based superalloy Inconel 600 and AISI 304L austenitic stainless steel with friction welding. They welded with the parameters of $35 \mathrm{MPa}$ friction pressure, $3 \mathrm{~s}$ friction time, $35 \mathrm{MPa}$ forge pressure, $3 \mathrm{~s}$ forge time and $1000 \mathrm{rpm}$ rotational speed. Tensile strength, hot tensile strength, charpy impact strength, hardness distribution and microstructure were evaluated in the welds. As a result, the maximum tensile strength was found to be $500 \mathrm{MPa}$ and the maximum tensile strength at $300{ }^{\circ} \mathrm{C}$ was $487 \mathrm{MPa}$. They found a maximum hardness of $216 \mathrm{HV}$ near the weld interface of the Inconel 600 superalloy and $199 \mathrm{HV}$ in AISI 304L austenitic stainless steel [9].

Cavuşoglu N. welded Inconel 713C and AISI 4140 materials with friction welding in his study. The rotation speed was fixed at $2400 \mathrm{rpm}$ in all welding processes. In addition, he welded these two different metals with 9 different welding parameters by changing the friction pressure, friction time, forge pressure and forge time. He investigated metallurgical changes in tensile strength, hardness and microstructure on welded specimens. The highest strength was found to be $718 \mathrm{~N} / \mathrm{mm} 2$ with the parameters of $20 \mathrm{~kg} / \mathrm{cm} 2$ friction pressure, $15 \mathrm{~s}$ friction time, $50 \mathrm{~kg} / \mathrm{cm} 2$ forge pressure and $3 \mathrm{~s}$ forge time. He stated that all of the welded samples had an increase in hardness in the HAZ. He was stated in the tensile tests that the rupture occurred in AISI 4140 steel. As a result, with SEM and EDS analyzes, $\gamma$ and $\gamma^{\prime}-\mathrm{Ni}_{3}(\mathrm{Al}, \mathrm{Ti})$ phases were observed in the matrix at the friction welding joints and $\gamma^{\prime \prime}$. $\mathrm{Ni}_{3} \mathrm{Nb}$ phases at the grain boundaries. He also showed that the carbides deposited at the grain boundaries were formed by $\mathrm{Nb}$ [10].

In this study, nickel-based alloy Inconel 718 super alloy and AISI 316L stainless steel were welded with continuous friction welding. Welding samples of $12 \mathrm{~mm}$ diameter and $70 \mathrm{~mm}$ length were prepared for Inconel 718 and AISI 316L. In the friction welding machine, AISI $316 \mathrm{~L}$ stainless steel is attached to the rotating chuck and Inconel 718 superalloy is attached to the linear moving chuck. For continuous friction welding parameters, 3 different rotational speeds (1800-1600-1400 rpm), 3 different friction times for each rotational speed (16-12-6 seconds) and 3 different friction pressures (60- 40-20 MPa), forge pressure (120$80-40 \mathrm{MPa})$ and forge time (32-24-12 s) were determined. In line 
with these parameters, there were welded 27 different samples. The axial shortenings of the samples which welded with these parameters were measured with the digital caliper. Thus, when these two different materials are welded with friction welding, it will be predicted how much they will shorten in axial length.

\section{Material and Method}

Inconel 718 which is determined for welding, is called a nickel-based superalloy. It has excellent oxidation and corrosion resistance along with high tensile and creep properties. The chemical properties of this superalloy are given in Table 1. Another welded part is Fe based AISI 316L stainless steel. Stainless steels are known for their good ductility, reasonable formability, excellent corrosion resistance and high toughness. The chemical properties of AISI 316L stainless steel are given in Table 2.

Table 1. Chemical Composition of Inconel 718 [11]

\begin{tabular}{|l|l|l|l|l|l|l|l|l|}
\hline Element & $\mathbf{N i}$ & $\mathbf{C r}$ & $\mathbf{F e}$ & $\mathbf{N b}$ & $\mathbf{M o}$ & $\mathbf{C o}$ & $\mathbf{T i}$ & $\mathbf{A l}$ \\
\hline wt.\% & $50 \sim 55$ & $17 \sim 21$ & $\mathrm{Bal}$. & $4.75 \sim 5.5$ & $2.8 \sim 3.3$ & $<1.0$ & $0.65 \sim 1.15$ & $0.20 \sim 0.80$ \\
\hline Element & $\mathbf{M n}$ & $\mathbf{S i}$ & $\mathbf{C u}$ & $\mathbf{C}$ & $\mathbf{P}$ & $\mathbf{S}$ & $\mathbf{B}$ & \\
\hline wt.\% & $<0.35$ & $<0.35$ & $<0.3$ & $<0.08$ & $<0.015$ & $<0.0015$ & $<0.006$ & \\
\hline
\end{tabular}

Table 2. Chemical Composition of AISI 316L [12]

\begin{tabular}{|l|l|l|l|l|l|l|l|l|l|}
\hline Element & $\mathbf{C}$ & $\mathbf{S i}$ & $\mathbf{M n}$ & $\mathbf{C r}$ & Ni & Mo & S & $\mathbf{P}$ & Fe \\
\hline wt.\% & 0.03 & 1.0 & 2.0 & $16.0 \sim 18.0$ & $10.0 \sim 14.0$ & $2.0 \sim 3.0$ & 0.03 & 0.045 & Balance \\
\hline
\end{tabular}

Inconel 718 superalloy and AISI 316L stainless steel taken as full length are cut to $70 \mathrm{~mm}$ length. In order to ensure that all the surfaces to be welded on the cut samples are of the same surface quality, the samples were subjected to sanding with 180-600-1200 mesh SiC sandpapers. The sanded surfaces were polished to the broadcloth as a final operation before the friction welding process. The samples were cleaned in an ultrasonic bath at $40{ }^{\circ} \mathrm{C}$ for 5 minutes in $10 \%$ acetone solution before welding.

Friction welding specimens were welded in Firat University, Faculty of Technical Education, Department of Metal Education. The photo of the welding machine is given in Figure 1 [13].

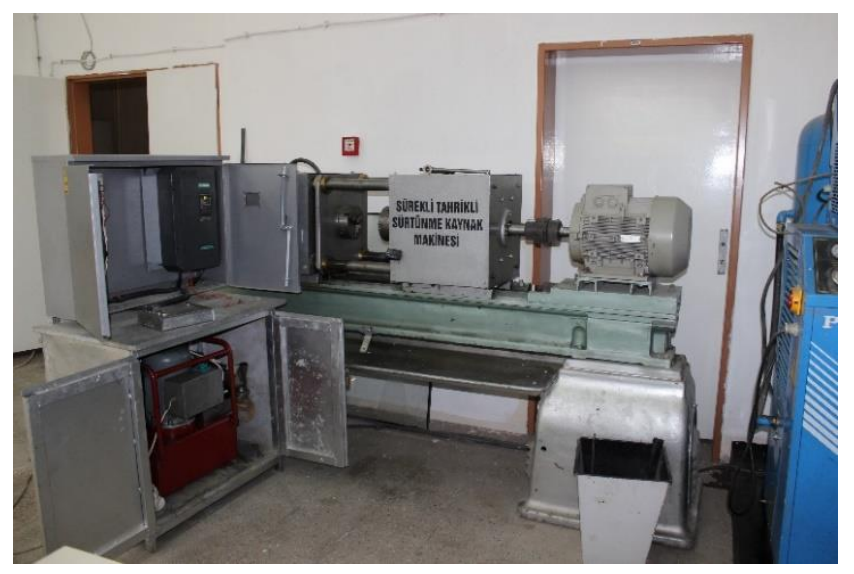

Figure 1. Continuous friction welding machine

For friction welding, AISI $316 \mathrm{~L}$ stainless steel is attached to the rotating chuck and Inconel 718 superalloy is attached to the linear moving chuck, and all welding samples are weld.

Welding schematic and sample dimensions are given in Figure 2.

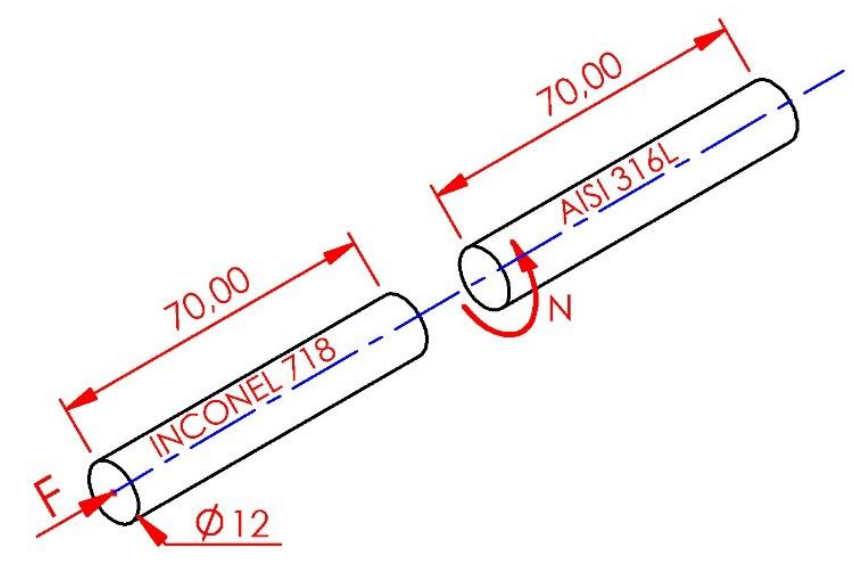

Figure 2. Sample dimensions and friction welding schematic

Before welding, approximate welding parameters were determined with a few experiments. A total of 108 welded samples were made with 27 different welding parameters. Welding parameters are given in Table 3.

Table 3. Friction welding parameters

\begin{tabular}{|c|c|c|c|c|c|}
\hline \multirow{2}{*}{ 产 } & \multicolumn{5}{|c|}{ Specified Parameters } \\
\hline & $\begin{array}{c}\text { Rotation } \\
\text { Speed } \\
\text { (rpm) } \\
\end{array}$ & \begin{tabular}{|c|} 
Friction \\
Time \\
$(\mathrm{s})$ \\
\end{tabular} & $\begin{array}{c}\text { Friction } \\
\text { Pressure } \\
\text { (MPa) } \\
\end{array}$ & \begin{tabular}{|c|} 
Forge \\
Pressure \\
(MPa) \\
\end{tabular} & \begin{tabular}{|c} 
Forge \\
Time \\
$(\mathrm{s})$ \\
\end{tabular} \\
\hline S1 & \multirow{9}{*}{1800} & \multirow{3}{*}{16} & 60 & 120 & \multirow{3}{*}{32} \\
\hline $\mathbf{S 2}$ & & & 40 & 80 & \\
\hline $\mathbf{S 3}$ & & & 20 & 40 & \\
\hline S4 & & \multirow{3}{*}{12} & 60 & 120 & \multirow{3}{*}{24} \\
\hline S5 & & & 40 & 80 & \\
\hline S6 & & & 20 & 40 & \\
\hline $\mathbf{S 7}$ & & \multirow{3}{*}{6} & 60 & 120 & \multirow{3}{*}{12} \\
\hline S8 & & & 40 & 80 & \\
\hline S9 & & & 20 & 40 & \\
\hline $\mathbf{S 1 0}$ & \multirow{2}{*}{1600} & \multirow{2}{*}{16} & 60 & 120 & \multirow{2}{*}{32} \\
\hline S11 & & & 40 & 80 & \\
\hline
\end{tabular}

313 


\begin{tabular}{|c|c|c|c|c|c|}
\hline S12 & & & 20 & 40 & \\
\hline S13 & & \multirow{3}{*}{12} & 60 & 120 & \multirow{3}{*}{24} \\
\hline S14 & & & 40 & 80 & \\
\hline S15 & & & 20 & 40 & \\
\hline S16 & & \multirow{3}{*}{6} & 60 & 120 & \multirow{3}{*}{12} \\
\hline $\mathbf{S 1 7}$ & & & 40 & 80 & \\
\hline S18 & & & 20 & 40 & \\
\hline S19 & \multirow{9}{*}{1400} & \multirow{3}{*}{16} & 60 & 120 & \multirow{3}{*}{32} \\
\hline $\mathbf{S 2 0}$ & & & 40 & 80 & \\
\hline S21 & & & 20 & 40 & \\
\hline $\mathbf{S 2 2}$ & & \multirow{3}{*}{12} & 60 & 120 & \multirow{3}{*}{24} \\
\hline $\mathbf{S 2 3}$ & & & 40 & 80 & \\
\hline S24 & & & 20 & 40 & \\
\hline $\mathbf{S 2 5}$ & & \multirow{3}{*}{6} & 60 & 120 & \multirow{3}{*}{12} \\
\hline $\mathbf{S 2 6}$ & & & 40 & 80 & \\
\hline S27 & & & 20 & 40 & \\
\hline
\end{tabular}

Photographs of the welded S1, S2, S3 samples are given in Figure 3.

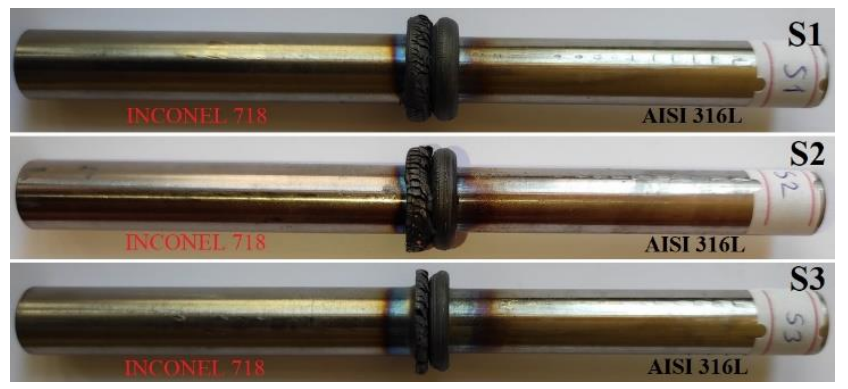

Figure 3. Welded samples S1, S2 and S3

Photographs of the welded S2, S5, S8 samples are given in Figure 4.

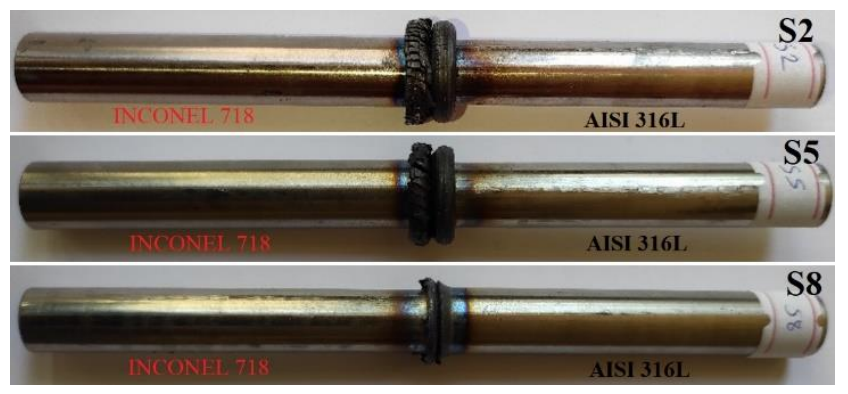

Figure 4. Welded samples $S 2, S 5$ and $S 8$

The photographs of the welded S1, S10, S19 samples are given in Figure 5.

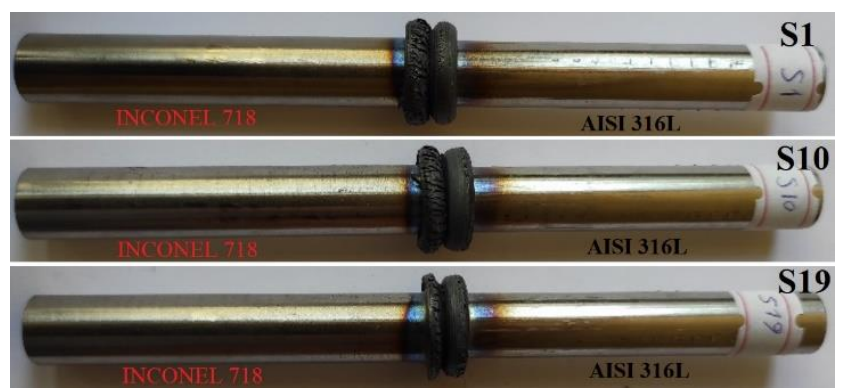

Figure 5. Welded samples S1, S10 and S19
The welded samples were measured from the middle of the welding flash with a digital caliper and subtracted from the total length of $70 \mathrm{~mm}$, and the axial shortening was calculated.

\section{Results and Discussion}

Axial shortenings in length for Inconel 718 and AISI 316L samples are given in Figure 6 in graphic form. The total length axial shortening in welded samples is given in Table 4.

In this study, the axial shortening of the samples was evaluated according to the change in welding parameters. At the same time, the effect of changes in parameters such as rotational speed, friction time, friction pressure, forge pressure and forge time on the axial shortening of friction welded samples has been interpreted. There is no study in the literature joining Inconel 718 superalloy and AISI 316L stainless steel with continuous friction welding. With these data, it will be predicted how much the length of the post-weld parts will be shortened in academic or commercial studies to be carried out afterwards. Thus, it will be useful to determine the initial lengths of the parts to be welded.

Table 4. Total axial shortening of welded samples

\begin{tabular}{|c|c|c|c|}
\hline 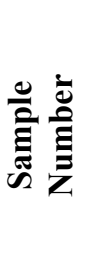 & 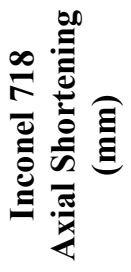 & 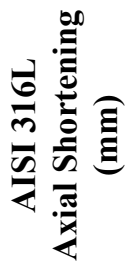 & 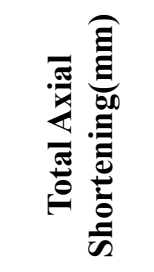 \\
\hline S1 & 2,9 & 5,67 & 8,57 (Max) \\
\hline S2 & 2,84 & 5,43 & 8,27 \\
\hline S3 & 1,75 & 3,89 & 5,64 \\
\hline S4 & 2,58 & 4,68 & 7,26 \\
\hline S5 & 1,61 & 3,63 & 5,24 \\
\hline S6 & 1,01 & 2,27 & 3,28 \\
\hline S7 & 1 & 2,53 & 3,53 \\
\hline S8 & 0,57 & 1,62 & 2,19 \\
\hline S9 & 0,26 & 1,24 & 1,5 \\
\hline S10 & 2,81 & 5,23 & 8,04 \\
\hline S11 & 2,16 & 3,13 & 5,29 \\
\hline S12 & 1,95 & 4,12 & 6,07 \\
\hline S13 & 2,15 & 4,26 & 6,41 \\
\hline S14 & 1,21 & 3,11 & 4,32 \\
\hline S15 & 1,08 & 2,65 & 3,73 \\
\hline S16 & 0,75 & 2,13 & 2,88 \\
\hline S17 & 0,45 & 1,86 & 2,31 \\
\hline S18 & 0,27 & 1,12 & 1,39(Min) \\
\hline S19 & 2,12 & 4,24 & 6,36 \\
\hline $\mathbf{S 2 0}$ & 2,24 & 4,46 & 6,7 \\
\hline S21 & 2,3 & 4,61 & 6,91 \\
\hline S22 & 1,51 & 3,16 & 4,67 \\
\hline $\mathbf{S 2 3}$ & 1,77 & 3,47 & 5,24 \\
\hline S24 & 1,13 & 2,97 & 4,1 \\
\hline $\mathbf{S 2 5}$ & 0,44 & 1,13 & 1,57 \\
\hline S26 & 0,27 & 1,57 & 1,84 \\
\hline S27 & 0,39 & 1,63 & 2,02 \\
\hline
\end{tabular}




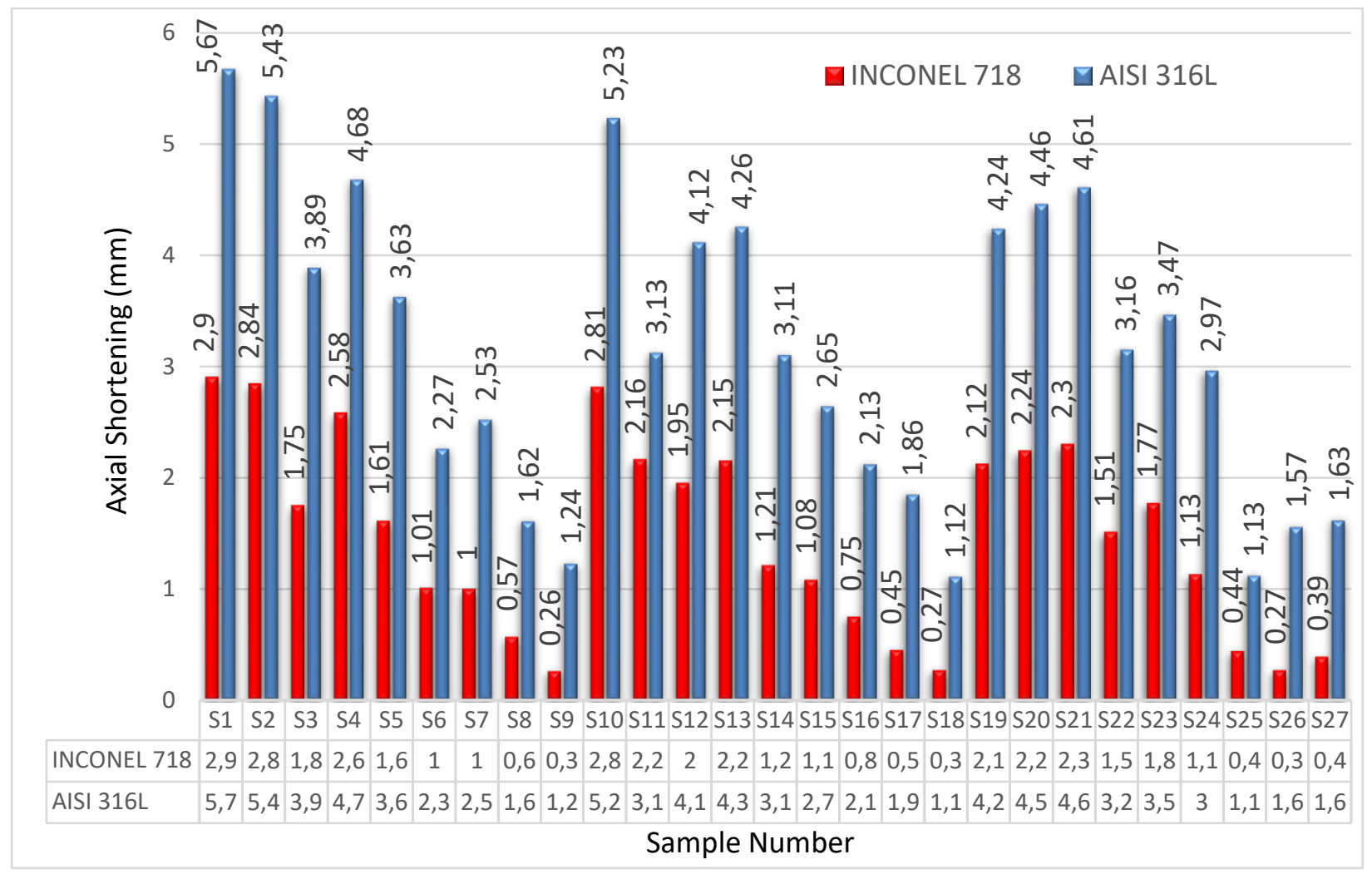

Figure 6. Axial shortening graph for Inconel 718 and AISI $316 \mathrm{~L}$

\section{Conclusions and Recommendations}

The axial shortening of the samples was evaluated for 27 different welding parameters in the joining of nickel-based Inconel 718 superalloy and AISI 316L stainless steel with friction welding. In all welds, it has been observed that the axial shortening in AISI $316 \mathrm{~L}$ material is more than Inconel 718 material. The axial shortening in the total length of the samples was observed to be $8.57 \mathrm{~mm}$ at the most in the $\mathrm{S} 1$ sample and as $1.39 \mathrm{~mm}$ at the least in the S18 sample. When the welded samples are examined in macro terms, it has been seen that the HAZ is narrower on the Inconel 718 side. In addition, cracks were observed in the welding flash of Inconel 718 material. It was observed that axial shortening in length increased as friction and forge pressure increased at $1800 \mathrm{rpm}$ and $1600 \mathrm{rpm}$. The increase in friction and forge time increased the axial shortening in all samples.

In future studies, the tensile strength, hardness distribution, creep strength and microstructure of these welded parts will be evaluated.

\section{Acknowledge}

This work is supported by the Scientific Research Project Fund of Sivas Cumhuriyet University under the project number M-789.

\section{References}

[1] E. T. Akinlabi and R. M. Mahamood, Solid-State Welding : Friction and Friction Stir Welding Processes. 2020.

[2] A. Dede, U. Soy, and S. Aslanlar, "Sürtünme Kaynak Yöntemi," SAU Fen Bilim. Enstitüsü Derg., vol. 6, no. 1, pp. 7-12, 2002.

[3] M. Maalekian, "Friction welding-critical assessment of literature," Sci. Technol. Weld. Join., vol. 12, no. 8, pp. 738-759, 2007.

[4] I. Kirik and N. Ozdemir, "Effect of process parameters on the microstructure and mechanical properties of frictionwelded joints of aisi 1040/aisi 3041 steels," Mater. Tehnol., vol. 49, no. 5, pp. 825-832, 2015.

[5] A. P. Ramesh, M. Subramaniyan, and P. Eswaran, "Review on friction welding of similar/dissimilar metals," J. Phys. Conf. Ser, vol. 1362, no. 1, Nov. 2019.

[6] S. V. Lalam, G. M. Reddy, T. Mohandas, M. Kamaraj, and B. S. Murty, "Continuous drive friction welding of Inconel 718 and EN24 dissimilar metal combination," Mater. Sci. Technol., vol. 25, no. 7, pp. 851-861, Jul. 2009.

[7] W. Y. Li et al., "Effect of friction time on flash shape and axial shortening of linear friction welded 45 steel," Mater. Lett., vol. 62, no. 2, pp. 293-296, Jan. 2008.

[8] A. U. Rehman, Y. Usmani, A. M. Al-Samhan, and S. Anwar, "Rotary Friction Welding of Inconel 718 to Inconel 600," Met. 2021, Vol. 11, Page 244, vol. 11, no. 2, p. 244, Feb. 2021.

[9] N. Gobu and K. Mahadevan, "Evaluation Of Mechanical And Metallurgical Properties Of Friction Welded Inconel 600 And A1s1 3041 Austenitıc Stainless Steel Dissimilar Joints," J. Manuf. Eng., vol. 11, no. 3, pp. 171-177, 2016, Accessed: Feb. 26, 2022.

[10]N. Cavuşoglu, "Effect of Friction Welding Parameters on 
the Mechanical and Microstructural Properties of Dissimilar IN713C-AISI 4140 Joints," J. Mater. Eng. Perform., pp. 1-14, Jan. 2022.

[11]"ASM Material Data Sheet Inconel 718." http://asm.matweb.com/search/SpecificMaterial.asp?bassn um=NINC34 (accessed Feb. 27, 2022).

[12]"316L Stainless Steel Chemical Properties." https://bircelik.com/tr/kategori/3161-1-4404- (accessed Feb. 27, 2022).

[13]Kirik I. and Ozdemir N., "Otomotiv Endüstrisinde Kullanılan Sürtünme Kaynak Makinesi İmalatı ve Farklı Özellikteki AISI 1040/AISI 3041 Çelik Çiftlerinin Sürtünme Enerjisi Kullanılarak Birleştirilmesi," e-Journal New World Sci. Acad., vol. 7, no. 3, pp. 60-72, 2012, Accessed: Feb. 27, 2022. 